\title{
PENGARUH EARNINGS PER SHARE, NET PROFIT MARGIN, DEBT TO EQUITY RATIO TERHADAP HARGA SAHAM
}

\author{
Taufan Septiawan dan Erna Hernawati \\ tauvandersar@gmail.com,erna_hernawati@yahoo.com \\ Fakultas Ekonomi UPN "Veteran” Jakarta \\ Jl. R.S. Fatmawati Pondok Labu, Jakarta Selatan - 12450
}

\begin{abstract}
This study was conducted to examine the effect of Earnings Per Share, Net Profit Margin, Debt to Equity Ratio toward Stock Price on manufacturing companies in Indonesia Stock Exchange during the years 2009-2012. The population consists of 36 companies and are used as a sample of 17 companies. Sampling technique using purposive sampling method. Data were tested by using multiple regression analysis and hypothesis test with $5 \%$ level of confidence. The research results that the variables Earnings Per Share (EPS) and Net Profit Margin (NPM) gives significantly positive effect on Stock Price. The other variables Debt to Equity Ratio is not significantly to Stock Price. We suggest for investors in Indonesia Stock Exchange that paying attention other factors that regards Stock Price because with those information they can make the best decision for their investments.
\end{abstract}

Keywords: Debt to Equity Ratio, Earnings Per Share, Net Profit Margin,

\section{PENDAHULUAN}

\section{Latar Belakang Penelitian}

Pasar modal merupakan tempat diperjualbelikannya berbagai instrument keuangan jangka panjang, seperti utang, ekuitas (saham), dan isntrumen lainnya. Pasar modal juga merupakan sarana pendanaan bagi perusahaan, karena pasar modal berfungsi sebagai lembaga perantara yang dapat menghubungkan pihak yang membutuhkan dana dengan pihak yang mempunyai kelebihan dana. Dengan kata lain pasar modal adalah salah satu tempat yang sangat ideal bagi investor atau perusahaan untuk menginvestasikan modal yang dimilikinya. (Darmadji, 2011:1)

Undang-Undang Nomor 8 Tahun 1995 tentang Pasar Modal memberikan pengertian yang lebih spesifik mengenai pasar modal yaitu kegiatan yang bersangkutan dengan penawaran umum dan perdagangan efek, perusahaan publik yang berkaitan dengan efek yang diterbitkannya, seerta lembaga dan profesi yang berkaitan dengan efek.

Dalam perkembangannya, pasar modal membawa peranan yang cukup penting dalam kegiatan perekonomian. Bahkan pasar modal juga dapat dipandang sebagai salah satu barometer kondisi perekonomian suatu negara. Masyarakat semakin memandang pasar modal sebagai salah satu alternative dalam menginvestasikan dana yang mereka miliki. Dengan dijualnya saham di pasar modal berarti masyarakat diberi kesempatan untuk memiliki dan menikmati keuntungan yang diperoleh 
perusahaan. Dengan kata lain, pasar modal dapat membantu pemerintah meningkatkan pendapatan masyarakat (Anoraga, 2006:8)

Harga saham mencerminkan nilai dari suatu perusahaan. Jika perusahaan mencapai prestasi yang baik, maka saham perusahaan tersebut akan banyak diminati oleh para investor. Prestasi baik yang dicapai perusahaan dapat dilihat dari laporan keuangan yang dipublikasikan oleh perusahaan (emiten) (Husaini:2012). Laporan keuangan sangat berguna bagi investor untuk menentukan keputusan investasi yang terbaik dan menguntungkan. Berdasarkan analisis terhadap laporan keuangan, investor bisa mengetahui perbandingan antara nilai intrinsik saham perusahaan dibanding harga pasar saham perusahaan bersangkutan, dan atas dasar perbandingan tersebut investor akan bisa membuat keputusan apakah membeli atau menjual saham bersangkutan. (Tandelilin,2010:365).

Perusahaan yang memiliki kinerja yang baik harga sahamnya bisa saja turun karena keadaan pasar yang jelek (bearish) yang menyebabkan kepercayaan terhadap pemodal terguncang, namun saham ini tidak akan sampai hilang jika kepercayaan pemodal kembali pulih. Untuk memastikan apakah kinerja perusahaan tersebut berada dalam kondisi baik atau buruk dapat dilakukan dengan menggunakan analisis rasio (Anisma : 2012).

Analisa terhadap penilaian harga saham merupakan langkah mendasar yang harus dilakukan oleh investor sebelum melakukan investasi, suapaya investor tidak terjebak pada kondisi yang merugikan. Dimana harga saham di bursa efek ditentukan menurut hukum permintaan dan penawaran. Semakin banyak orang ingin membeli saham, maka harga saham akan cenderung naik, sebaliknya semakin banyak orangorang yang akan menjual saham tersebut maka harga saham akan cenderung turun (Wijayanti:2010)

Salah satu analisa terhadap penilaian harga saham adalah dengan menggunakan analisis rasio keuangan. Rasio keuangan digunakan untuk menilai kinerja manajemen dalam suatu periode apakah mencapai target seperti yang telah ditetapkan. Ada beberapa jenis rasio keuangan yaitu rasio likuiditas, solvabilitas, aktiviti, profitabilitas, pertumbuhan, dan penilaian.

EPS merupakan informasi yang paling mendasar dan berguna, karena bisa menggambarkan prospek Earnings perusahaan di masa depan. Menurut Kashmir (2011:207) Rasio laba per lembar saham atau disebut juga rasio nilai buku merupakan rasio untuk mengukur keberhasilan manajemen dalam mencapai keuntungan bagi pemegang saham. Rasio yang rendah berarti manajemen belum berhasil untuk memuaskan pemegang saham, sebaliknya dengan rasio yang tinggi, kesejahteraan pemegang saham meningkat.

Cara lain untuk menganalisa harga saham selain EPS adalah dengan menghitung Net Profit Margin (NPM). NPM merupakan ukuran yang digunakan dalam memantau seberapa banyak keuntungan operasional yang diperoleh dari setiap penjualan. Semakin tinggi nilai rasio ini, 
menunjukan bahwa profitabilitas perusahaan semakin baik sehingga investor tertarik untuk menanamkan modal (Qoribulloh:2013).

Solvabilitas suatu perusahaan menggambarkan kemampuan suatu perusahaan dalam memenuhi kewajiban jangka panjangnya. Rasio yang digunakan untuk mengukur kemampuan ini salah satunya adalah Debt to Equity Ratio. Dalam rangka mengukur risiko, fokus perhatian kreditor jangka panjang terutama ditujukan pada prospek laba dan perkiraan arus kas. Meskipun demikian, mereka tidak dapat mengabaikan pentingnya tetap mempertahankan keseimbangan antara proporsi aktiva yang didanai oleh kreditor dan didanai oleh pemilik perusahaan. Keseimbangan proporsi antara aktiva yang didanai oleh kreditor dan yang didanai oleh pemilik perusahaan diukur dengan rasio Debt to Equity Ratio (Prastowo,2011:89).

Banyak perusahaan yang terdaftar di BEI, salah satunya adalah PT. Gudang Garam Tbk. (GGRM). Laba PT Gudang Garam Tbk (GGRM) tergerus $17,8 \%$ di akhir 2012 menjadi $\mathrm{Rp}$ 4,09 triliun, dari sebelumnya ditahun 2011 sebesar Rp 4,98 triliun. Laba terkikis oleh beban pokok penjualan yang naik tinggi. Beban pokok penjualan naik tinggi membuat rasio beban terhadap pendapatan semakin sempit. Beban pokok penjualan emiten berkode GGRM itu naik menjadi Rp 39,84 triliun di 2012. Tingginya beban penjualan membuat laba usaha yang dibukukan menjadi Rp 6,02 triliun. Koreksi yang terjadi pada pos laba itu membuat laba per saham dasar ikut berkurang, dari Rp
2554 per lembar saham menjadi hanya Rp 2086 per lembar saham pada akhir tahun 2012. Namun pada perdagangan harga saham GGRM naik 800 poin $(1,7 \%)$ ke level Rp 47800 per lembar.

Berbagai penelitian terdahulu yang dilakukan mengenai harga saham telah dilakukan yang mendasari penelitian ini. Penelitian yang dilakukan oleh Obeidat (2009) menunjukan bahwa EPS memiliki pengaruh yang signifikan terhadap harga saham. Hal ini juga didukung oleh penelitian yang dilakukan oleh Wijayanti (2010), Nurfadillah (2012), dan Atika Jauhari (2012) yang menyatakan bahwa EPS berpengaruh signifikan terhadap harga saham. Namun hasil ini berlawanan dengan penelitian yang dilakukan oleh Yenni Sugiarti (2009) yang menyatakan bahwa EPS tidak berpengaruh terhadap Harga Saham. Hasil tersebut juga didukung oleh penelitian lain yang dilakukan oleh Fadia Zen (2009) dan Meythi (2010) yang menyatakan hasil yang sama.

Penelitian terdahulu mengenai Pengaruh Net Profit Margin terhadap Harga Saham telah dilakukan oleh Yuneita Anisma (2012) yang menyatakan bahwa Net Profit Margin (NPM) memiliki pengaruh yang signifikan terhadap Harga Saham. Hasil tersebut didukung oleh penelitian lain yang dilakukan oleh Rescyana Putri Hutami (2012) yang juga menyatakan bahwa NPM berpengaruh Signifikan terhadap Harga Saham. Di penelitian lain yang dilakukan oleh Ahmad Husaini (2012) menyebutkan bahwa NPM tidak berpengaruh signifikan terhadap Harga Saham. Hasil tersebut 
berlawanan dengan hasil penelitian sebelumnya.

Penelitian terdahulu juga meneliti mengenai pengaruh Debt to Equity Ratio terhadap Harga Saham. Penelitian yang dilakukan oleh Stella (2009) dan Atika Jauhari menyatakan bahwa DER berpengaruh negatif terhadap Harga Saham. Sedangkan hasil berlawanan ditemukan dalam penelitian yang dilakukan oleh Edi Subiyantoro (2003) yang menyebutkan bahwa DER tidak berpengaruh signifikan terhadap Harga Saham. Hasil ini juga didukung oleh penelitian lain yang dilakukan Njo Anastasia (2003), Nurfadillah (2011) yang menyatakan bahwa DER tidak berpengaruh terhadap Harga Saham.

\section{Perumusan Masalah}

Ruang lingkup dari penelitian ini mencakup bidang ilmu ekonomi akuntansi, khususnya membahas tentang pasar modal yang didalamnya mencakup Earnings Per Share (EPS) Net Profit Margin (NPM) dan Debt to Equity Ratio (DER) sebagai variable independen dan Harga Saham sebagai variable dependen. Berdasarkan latar belakang di atas maka timbul permasalahan sebagai berikut:

1. Apakah variabel Earnings Per Share (EPS) berpengaruh signifikan terhadap Harga Saham?

2. Apakah variabel Net Profit Margin (NPM) berpengaruh signifikan terhadap Harga Saham?

3. Apakah variabel Debt to Equity Ratio (DER) berpengaruh signifikan terhadap Harga Saham?
TINJAUAN PUSTAKA DAN PENGEMBANGAN HIPOTESIS

Teori Sinyal

Sinyal adalah suatu tindakan yang diambil oleh manajemen suatu perusahaan memberikan petunjuk kepada investor tentang bagaimana manajemen menilai prospek perusahaan tersebut.Setiap orang baik investor maupun manajer memiliki informasi yang sama tentang prospek suatu perusahaan. Hal ini disebut juga sebagai informasi simetris (symmetric information).Namun, pada kenyataannya manajer sering kali memiliki informasi yang lebih baik dibandingkan dengan investor luar.Hal ini disebut juga dengan informasi asimetris

Information).Perusahaan dengan prospek yang sangat cerah lebih memilih untuk tidak melakukan pendanaan melalui penawaran saham baru, sementara perusahaan dengan prospek yang buruk memang menyukai pendanaan ekuitas luar. Secara garis besar, pengumuman penawaran saham biasanya dianggap sebagai suatu sinyal bahwa prospek perusahaan kurang cerah menurut penilaian manajemennya (Brigham dan Houston ,2011 : 184-186).

\section{Pengembangan Hipotesis Earnings Per Share}

Bagi para investor, informasi EPS merupakan informasi yang dianggap paling mendasar dan berguna, karena bisa menggambarkan prospek Earnings perusahaan di masa depan. Besarnya EPS suatu perusahaan bisa diketahui dari informasi laporan keuangan perusahaan. Meskipun beberapa 
perusahaan tidak mencantumkan besarnya EPS perusahaan bersangkutan dalam laporan keuangannya. Berikut ini adalah pernyataan para ahli mengenai Earningsper share: Menurut Tandelilin (2010:374) menyatakan bahwa "EPS menunjukan besarnya laba bersih perusahaan yang siap dibagikan bagi semua pemegang saham perusahaan."

\section{Net Profit Margin}

Rasio kemampuan memperoleh laba perusahaan tergantung dari laba dan modal mana yang diperhitungkan. Jenis laba perusahaan bermacammacam tingkatannya mulai dari laba kotor, laba usaha, laba sebelum bunga dan pajak, laba kena pajak dan laba bersih perusahaan. Tentunya agar rasio profitabilitas ini mempunyai arti, maka rasio laba dengan modal harus disesuaikan dengan dari mana laba dan modal itu ditunjukan. Salah satu perhitungan yang digunakan untuk mengukur rasio profitabilitas adalah Net Profit Margin. Berikut ini adalah berbagai pendapat dari para ahli mengenai pengertian NPM :Menurut Sitanggang (2012:30) menyatakan bahwa "NPM yaitu rasio yang mengukur seberapa besar tingkat keuntungan bersih perusahaan dari setiap penjualannya"Menurut Prastowo (2011:97) menyatakan bahwa "Rasio Net Profit Margin mengukur rupiah dan laba yang dihasilkan oleh setiap satu penjualan."Dari beberapa pendapat para ahli diatas mengenai Net Profit Margin, dapat diambil kesimpulan yang menjelaskan bahwa NPM adalah suatu rasio yang digunakan untuk mengetahui seberapa besar laba bersih yang dihasilkan oleh perusahaan dalam setiap penjualannya.

\section{Nilai Perusahaan}

Rasio utang adalah mengukur pembiayaan perusahaan dari sumber utang yang akan berdampak pada kewajiban atau beban tetap. Dengan demikian rasio leverage merupakan ukuran seberapa besar perusahaan dibiayai dari utang dan seberapa besar kemampuan perusahaan dari hasil operasi perusahaan untuk melunasi beban pembayaran bunga dan atau pokok pinjaman tersebut.Dalam dunia bisnis sekarang hampir tidak ada lagi perusahaan yang semata-mata dibiayai dari modal sendiri, tetapi merupakan sesuatu yang otomatis didukung dari modal utang seperti dengan melakukan pembelian secara kredit yang menimbulkan munculnya utang dagang. Disamping pembelian kredit, pembiayaan melalui jenis utang lainnya juga semuanya merupakan hasil keputusan pembiayaan yang berakibat pada kewajiban membayar sewa leasing barang modal (Sitanggang,2012:25).

Berikut ini adalah beberapa pendapat para ahli mengenai Debt To Equity Ratio (DER):Menurut Prastowo (2011:89) menyatakan bahwa "Debt to Equity Ratio memberikan gambaran mengenai struktur modal yang dimiliki oleh perusahaan sehingga dapat dilihat tingkat risiko tidak tertagihnya suatu utang."'Menurut Sitanggang (2012:25) menyatakan bahwa "Rasio antara total utang dengan total ekuitas dalam perusahaan yang memberi gambaran perbandingan antara total utang dengan modal sendiri (equity) perusahaan.'Dari beberapa pendapat para ahli diatas 
mengenai Debt to Equity Ratio, dapat diambil kesimpulan yang menjelaskan bahwa Debt to Equity Ratio atau DER adalah rasio yang digunakan untuk menghitung berapa perbandingan antara total utang dengan modal sendiri (equity) sehingga dapat dilihat risiko tidak tertagihnya suatu utang Hipotesis dalam penelitian ini adalah :

H1 : Earnings Per Share berpengaruh signifikan terhadap Harga Saham

H2 : Net Profit Margin berpengaruh signifikan terhadap Harga Saham.

H3 : Debt to Equity Ratio berpengaruh signifikan terhadap Harga Saham.

\section{Pengukuran dan Definisi Operasional Variabel}

Definisi Operasional dari variabel yang digunakan dalam penelitian ini adalah sebagai berikut:

a. Variabel Independen

1) Earnings Per Share $\left(\mathrm{X}_{1}\right)$

Earnings per share atau pendapatan per lembar saham adalah bentuk pemberian keuntungan yang diberikan kepada para pemegang saham dari setiap lembar saham yang dimiliki.

\section{Earning After}

Earnings Per Share $=\frac{\text { Interest And Tax }}{\text { Outstanding Shares }}$

2) Net Profit Margin $\left(\mathrm{X}_{2}\right)$ Rasio ini bisa diinterpretasikan juga sebagai kemampuan perusahaan menekan biaya-biaya di perusahaan pada periode tertentu. Profit margin yang tinggi

menandakan

kemampuan

perusahaan

menghasilkan laba yang tinggi pada tingkat penjualan tertentu.

Earning After

Net Profit Margin $=\frac{\text { Interest And Tax }}{\text { Sales }}$

3) Debt To Equity Ratio $\left(\mathrm{X}_{3}\right)$

Rasio antara total utang dengan total ekuitas dalam perusahaan yang memberi gambaran perbandingan antara total utang dengan modal sendiri (equity) perusahaan.

Debt to Equity Ratio $=\frac{\text { Total Liabilities }}{\text { Total Equities }}$

b. Veriabel Dependen

Harga Saham (Y)

Pengukuran yang digunakan untuk menilai harga saham yaitu dengan menggunakan harga penutupan 5 hari setelah tanggal publikasi laporan keuangan perusahaan.

\section{METODE PENELITIAN}

\section{Populasi dan Pengambilan Sampel}

Populasi yang menjadi objek dalam penelitian ini adalah perusahaan manufaktur sektor industri barang konsumsi yang terdaftar di Bursa Efek Indonesia tahun 2009 sampai dengan 2012.Teknik pengambilan sampel yang digunakan adalah purposive sampling. Purposive sampling yaitu cara pengambilan sampel yang didasarkan pada pertimbanganpertimbangan tertentu (Sanusi, 2011:95).Adapun kriteria pemilihan sampel dalam penelitian ini adalah sebagai berikut :

1. Perusahaan yang masuk dalam sampel penelitian adalah 
perusahaan-perusahaan manufaktur sektor industri barang konsumsi yang listing di Bursa Efek Indonesia (BEI).

2. Perusahaan tidak pernah delisting dari BEI selama periode 2009 2012

3. Perusahaan sampel telah mempublikasikan laporan keuangan selama 4 (empat) tahun, yaitu mulai tahun 2009 sampai dengan 2012

4. Perusahaan yang masuk dalam sampel adalah perusahaan yang menghasilkan laba bersih selama 2009-2012.

\section{Teknik Analisis dan Uji Hipotesis}

Untuk mengetahui ada tidaknya pengaruh Earnings Per Share, Net Profit Margin, dan Debt Equity Ratio terhadap Harga Saham. Maka digunakan metode regresi berganda dan untuk mempermudah pelaksanaan perhitungan, penelitian ini menggunakan alat bantu IBM SPSS Statistic 20.0 (Statistical Product and Service Solutions) dan Microsoft Excel 2007.

\section{Teknik Analisis Data}

Teknik analisis yang digunakan dalam melakukan pengujian hipotesis dalam penelitian ini adalah analisis regresi berganda.Analisis ini dilakukan untuk mengetahui ada tidaknya pengaruh earnings per share, net profit margin dan debt to equity ratio sebagai variabel independen terhadap harga saham sebagai variabel dependen. Model persamaan yang digunakan:

$Y=\alpha+\beta_{1} X_{1}+\beta_{2} X_{2}+\beta_{3} X_{3}+e$

Dimana :

$$
\begin{array}{ll}
\mathrm{Y} & =\text { Harga Saham } \\
\mathrm{X} 1 & =\text { Earnings Per Share } \\
\mathrm{X} 2 & =\text { Net Profit Margin } \\
\mathrm{X} 3 & =\text { Debt to Equity Ratio } \\
\alpha & =\text { Konstanta } \\
\beta 1, \beta 2, \beta_{3}= & \text { Koefisien Regresi } \\
\mathrm{e} & =\text { Error }
\end{array}
$$

\section{Uji Hipotesis \\ Uji F (secara simultan)}

Uji $F$ ini digunakan untuk mengetahui ada tidaknya pengaruh secara bersama-sama (simultan) variabel-variabel independen (terikat). Pembuktian dilakukan dengan cara membandingkan nilai $\mathrm{F}$ hitung dengan $\mathrm{F}$ tabel pada tingkat kepercayaan 5\% dan derajat kebebasan (degree of freedom $) \mathrm{df}=(\mathrm{n}-\mathrm{k}-1)$ dimana $\mathrm{n}$ adalah jumlah responden dan $\mathrm{k}$ adalah jumlah variabel.Untuk mengetahui bahwa variabel independen (Earnings Per Share, Net Profit Margin, Debt Equity Ratio) secara simultan mempunyai pengaruh yang signifikan terhadap variabel dependen (Harga Saham).

Rumusan hipotesis dalam pengujian ini adalah sebagai berikut : Ho = Earnings Per Share, Net Profit Margin, Debt to Equity Ratio berpengaruh tidak signifikan terhadap Harga Saham

$\mathrm{Ha}=$ Earnings Per Share, Net Profit Margin, Debt to Equity Ratio berpengaruh signifikan terhadap Harga Saham

\section{$\mathbf{R}^{2}$ (Uji Koefisien Determinasi)}

Koefisien Determinasi $\left(\mathrm{R}^{2}\right)$ pada intinya untuk mengukur seberapa jauh kemampuan model dalam menerangkan variasi variabel dependen, untuk mengetahui seberapa besar persentase sumbangan dari 
variabel independen (Earnings Per Share, Net Profit Margin, Debt Equity Ratio) secara bersama - sama menjelaskan perubahan yang terjadi pada variabel dependen (Harga Saham).

\section{Uji t (uji parsial)}

Uji statistik $\mathrm{t}$ digunakan untuk mengetahui seberapa jauh pengaruh satu variabel penjelas (independen) secara individual dalam menerangkan variasi variabel dependen. $\mathrm{Uji} t$ dilakukan dengan membandingkan antara $t_{\text {hitung }}$ dengan $t_{\text {tabel }}$ dan tingkat signifikansi $5 \%$ dengan derajat kebebasan $\mathrm{df}=(\mathrm{n}-\mathrm{k}-1)$ dimana $\mathrm{n}$ adalah jumlah responden dan $\mathrm{k}$ adalah jumlah variabel.

Untuk mengetahui bahwa variabel independen (Earnings Per Share, Net Profit Margin, Debt Equity Ratio) secara parsial mempunyai pengaruh yang signifikan terhadap variabel dependen (Harga Saham).Rumusan hipotesis dalam pengujian ini adalah sebagai berikut :

1) Variabel Earnings Per Share mempunyai pengaruh terhadap Harga Saham

$\mathrm{H}_{\mathrm{o}}: \beta_{1}=0$ Earnings Per Share tidak berpengaruh signifikan terhadap Harga Saham.

$\mathrm{H}_{\mathrm{a}}: \beta_{1} \neq 0$ Earnings Per Share berpengaruh signifikan terhadap Harga Saham.

2) Variabel Net Profit Margin mempunyai pengaruh terhadap Harga Saham.

$\mathrm{H}_{\mathrm{o}}: \beta_{2}=0 \quad$ Net Profit Margin tidak berpengaruh signifikan terhadap Harga Saham.
$\mathrm{H}_{\mathrm{a}}: \beta_{2} \neq 0$ Net Profit Margin berpengaruh signifikan terhadap Harga Saham

3) Variabel Debt Equity Ratio mempunyai pengaruh terhadap Harga Saham.

$\mathrm{H}_{\mathrm{o}}: \beta_{2}=0 \quad$ Debt Equity Ratio tidak berpengaruh signifikan terhadap Harga Saham.

$\mathrm{H}_{\mathrm{a}}: \beta_{2} \neq 0$ Debt Equity Ratio

berpengaruh signifikan terhadap

HargaSaham.

Berdasarkan dasar signifikansi, kriterianya adalah

- Jika signifikansi > 0,05 maka Ho diterima.

- Jika signifikansi < 0,05 maka Ho ditolak

\section{HASIL DAN PEMBAHASAN Analisis Deskriptif}

Analisis Deskriptif dilakukan agar dapat memberikan gambaran terhadap variabel-variabel yang digunakan dalam penelitian. Penelitian ini menggunakan tiga variabel independen yang bertujuan untuk mengetahui pengaruh Earnings Per Share, Net Profit Margin, Debt to Equity Ratio terhadap Harga Saham. Variabel dependen dalam penelitian ini adalah Harga Saham.Dalam penelitian ini terjadi data outlier karena ada data yang tidak berdistribusi secara normal sehingga data tersebut harus di eliminasi.Statistik deskriptif setelah dilakukan eliminasi data ekstrim mengalami perubahan yaitu jumlah (N) sebelum dilakukan eliminasi berjumlah 88 Sample dan setelah dilakukan eliminasi berjumlah 60 sample. 
Tabel 1. Statistik Deskriptif

\begin{tabular}{cccc}
\hline Variabel & Max & Min & Mean \\
\hline EPS & 571,43 & 0,69 & 80,7683 \\
NPM & 17,49 & 0,19 & 6,4033 \\
DER & 2,45 & 0,14 & 0,8045 \\
Harga & 7.360 & 81,00 & 1072,8800 \\
Saham & & & \\
\hline
\end{tabular}

Sumber:data diolah

Dari tabel 4.4 diatas dapat dilihat bahwa nilai minimum Earnings Per Share terdapat pada PT. Indofarma Tbk pada tahun 2009 sebesar Rp.0,69. Sedangkan nilai maksimum variabel EPS terdapat pada PT. Indofood Sukses Makmur Tbk pada tahun 2011sebesar Rp. 571.43.Nilai rata-rata variabel Earnings Per Share (EPS) sebesar Rp. 80.7683 yang artinya bahwa rata-rata perusahaan mendapatakan laba per lembar saham adalah sebesar Rp. 80.7683.

Nilai minimum variabel $\mathrm{Net}$ Profit Margin sebesar $0.19 \%$ yang artinya bahwa perusahaan tidak mampu memaksimalkan kinerja perusahaan untuk mendapatkan laba bersih dari setiap penjualan yang dihasilkan sehingga hanya mendapatkan nilai $-0.19 \%$.Nilai NPM terendah terdapat pada perusahaan PT Indofarma Tbk pada Tahun 2009.Sedangkan nilai maksimum variabel NPM mengalami perubahan menjadi sebesar $17.49 \%$ dari yang sebelumnya sebesar $29.60 \%$ yang artinya adalah kemampuan perusahaan untuk memaksimalkan kinerjanya dalam mendapatkan laba bersih dari setiap penjualan yang dilakukan mendapatkan nilai NPM sebesar $17.49 \%$. Nilai tertinggi NPM terdapat pada PT. Akasha Wira International Tbk pada tahun 2012.Nilai mean variabel Net Profit Margin (NPM) sebesar $6.4033 \%$ yang artinya adalah rata-rata perusahaan yang mendapatkan laba bersih dari setiap penjualannya adalah sebesar $6.4033 \%$.

Nilai minimum variabel Debt to Equity Ratio sebesar 0.14 yang artinya bahwa jumlah nilai rasio hutang terhadap ekuitas perusahaan terendah sebesar 0.14.Nilai DER terendah terdapat pada PT Mustika Ratu Tbk pada tahun 2010.Sedangkan nilai maksimum DER sebesar 2.45 yang artinya bahwa jumlah nilai rasio hutang terhadap ekuitas perusahaan tertinggi sebesar 2.45. Nilai DER tertinggi terdapat pada PT. Indofood Sukses Makmur Tbk pada tahun 2009.Nilai rata-rata variabel Debt to Equity Ratio sebesar 0.8045 Ini artinya bahwa rata-rata perusahaan memiliki rasio utang terhadap ekuitas adalah 0.8045 .

Nilai minimum harga saham sebesar 81.00 yang artinya adalah harga terendah dari setiap lembar saham yang diperdagangkan adalah sebesar Rp. 81.00.Harga Saham terendah terdapat pada PT. Indofarma Tbk. pada tahun 2010.Sedangkan nilai maksimum harga saham adalah sebesar Rp.7360 artinya adalah harga saham tertinggi dari setiap lembar saham yang diperdagangkan adalah sebesar Rp.7360. Harga saham tertinggi terdapat pada PT. Indofood Sukses Makmur Tbk pada tahun 2012. 


\section{Uji Normalitas}

Tabel 2 Hasil Uji Normalitas

One-Sample Kolmogorov-Smirnov Test

\begin{tabular}{|c|c|c|}
\hline & & $\begin{array}{l}\text { Unstandardized } \\
\text { Predicted Value }\end{array}$ \\
\hline $\mathrm{N}$ & & 60 \\
\hline \multirow[t]{3}{*}{ Normal Parameters ${ }^{\mathrm{a}, \mathrm{b}}$} & Mean & 1072.8800000 \\
\hline & Std. Deviation & 1219.25093754 \\
\hline & Absolute & .155 \\
\hline \multirow[t]{2}{*}{ Most Extreme Differences } & Positive & .127 \\
\hline & Negative & -.155 \\
\hline Kolmogorov-Smirnov Z & & 1.200 \\
\hline Asymp. Sig. (2-tailed) & & .112 \\
\hline
\end{tabular}

Dari tabel 4.8 diatas menunjukan bahwa nilai signifikansi 0.112 atau nilai signifikansi $>0.05$ (diatas 0.05). Maka nilai residual telah berdistribusi normal

\section{Uji Autokorelasi}

\section{Tabel 3 Hasil Uji Autokorelasi}

\begin{tabular}{|c|c|}
\hline Model & Durbin-Watson \\
\hline 1 & 1.770 \\
\hline
\end{tabular}

Dari hasil tabel uji autokorelasi tersebut diketahui bahwa nilai Durbin Watson (DW) sebesar 1.770. Nilai tersebut akan dibandingkan dengan nilai tabel Durbin Watson (DW), dengan nilai signifikansi sebesar 5\% atau $\alpha$ : 5\%. Oleh karena nilai DW 1.770 lebih besar dari batas atas (du) 1.6889 dan kurang dari 2.3111 (4-du), maka hal ini menyatakan bahwa tidak terdapat autokorelasi.

\section{Uji Heteroskedastisitas}

Uji heteroskedastisitas bertujuan menguji apakah dalam model regresi terjadi ketidaksamaan varians dari residual satu pengamatan ke pengamatan lain. Pengujian dalam penelitian ini dilakukan dengan melihat grafik scatterplot yaitu jika penyebaran tidak membentuk suatu pola tertentu maka keadaan homokedastisitas terpenuhi atau tidak terjadi heterokedastisitas. Hasil pengujian hetersokedastisitas dalam penelitian ini adalah sebagai berikut:

\section{Gambar grafik Scaterplot}

Scatterplot

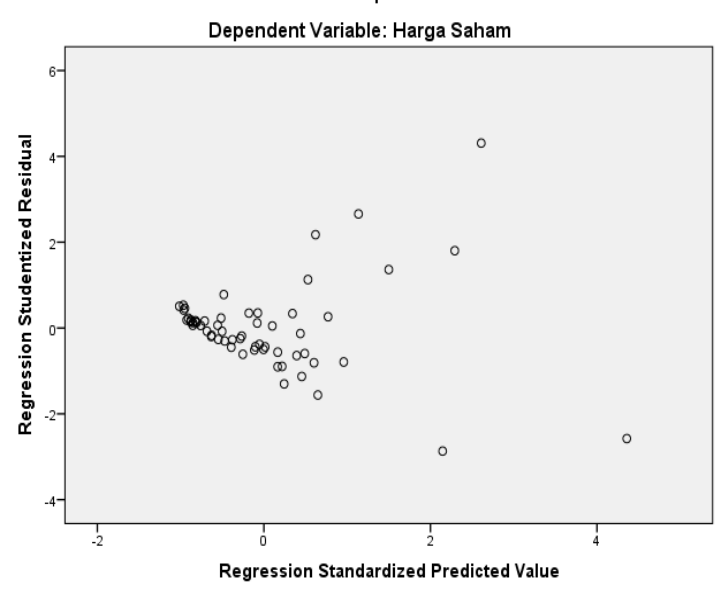

Dari hasil

uji heteroskedastisitas tersebut terlihat bahwa penyebaran plot terpencar dan tidak membentuk suatu pola tertentu. Dengan hasil demikian, dapat disimpulkan bahwa dalam penelitian ini tidak mengalami masalah heteroskedastisitas. 


\section{Uji Multikolinearitas}

Multikolinearitas terjadi jika nilai VIF lebih dari 10. Hasil nilai pengujian multikolinearitas dalam penelitian ini adalah sebagai berikut:

Tabel Uji Multikolinearitas

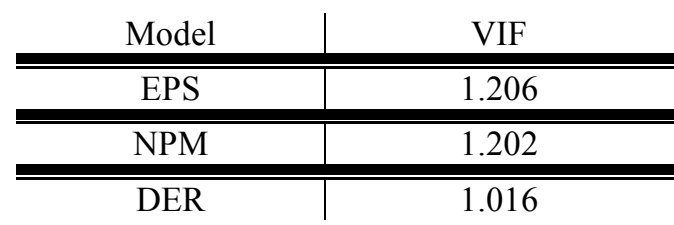

Dari hasil data pada tabel 4.10 diatas menunjukan bahwa hasil VIF untuk semua variabel independen masih lebih kecil dari $10(\mathrm{VIF}<10)$ sehingga dapat disimpulkan bahwa model regresi dalam penelitian ini tidak mengandung multikolinearitas.

\section{Hasil Uji F}

Pengujian menyeluruh atau uji F dilakukan untuk mengetahui bahwa variabel independen (EPS, NPM, dan DER) secara simultan mempunyai pengaruh yang signifikan terhadap variabel dependen (Harga Saham).

Tabel Uji F

\begin{tabular}{l|l|c|c|c}
\hline \multicolumn{2}{l|}{ Model } & $\begin{array}{c}\text { Sum of } \\
\text { Squares }\end{array}$ & F & Sig. \\
\hline \multirow{3}{*}{1} & Regression & 87707798.07 & 47.651 & $.000^{\mathrm{b}}$ \\
\cline { 2 - 5 } & Residual & 34358503.14 & & \\
\cline { 2 - 5 } & Total & 122066301.2 & &
\end{tabular}

Berdasarkan hasil uji simultan (Uji F) menunjukan bahwa nilai $F$ sebesar 47.651 dengan tingkat signifikansi sebesar 0.000. Karena signifikansi $<0,05$ (dibawah 0,05) maka Ho ditolak dan $\mathrm{Ha}$ diterima. Maka dapat disimpulkan bahwa variabel independen yaitu Earnings Per Share, Net Profit Margin, Debt to Equity Ratio secara simultan berpengaruh signifikan terhadap Harga Saham.

\section{Hasil Uji Koefisien Determinasi}

Koefisien determinasi $\left(\mathrm{R}^{2}\right)$ berguna untuk mengukur seberapa besar pengaruh variabel independen yaitu, Earnings Per Share, Net Profit Margin, Debt to Equity Ratio terhadap variabel dependen yaitu harga saham. Berikut ini merupakan hasil pengujian koefisien determinasi:

Tabel Koefisien Determinasi

\begin{tabular}{c|c|c|c}
\hline Model & R & R Square & Adj. R Square \\
\hline 1 & .848 & .719 & .703 \\
\hline
\end{tabular}

Berdasarkan tabel 4.12 diketahui bahwa nilai koefisien determinasi $\left(\mathrm{R}^{2}\right)$ dari Adjusted $\mathrm{R}$ Square sebesar 0.703. Hal ini menunjukan bahwa pengaruh Earnings Per Share, Net Profit Margin, Debt to Equity Ratio terhadap Harga Saham sebesar $70,3 \%$ sedangkan sisanya yaitu $29.7 \%$ dipengaruhi oleh variabel lain yang tidak diteliti dalam penelitian ini seperti ROA, ROE, dividen per share dan rasio keuangan lainnya

\section{Hasil Uji t}

Pengujian individu atau uji $t$ dilakukan untuk mengetahui pengaruh dari masing-masing variabel independen (EPS, NPM, dan DER) secara parsial mempunyai pengaruh yang signifikan terhadap variabel independen (Harga Saham). 
Tabel Uji t

\begin{tabular}{|c|c|c|}
\hline Model & $\mathrm{t}$ & Sig. \\
\hline (Constant) & -1.397 & .168 \\
\hline EPS & 9.494 & .000 \\
\hline NPM & 2.594 & .012 \\
\hline DER & .987 & .328 \\
\hline
\end{tabular}

Berdasarkan pada tabel 4.13 diatas menunjukan bahwa variabel EPS didapat nilai $t$ sebesar 9.494 dengan tingkat signifikansi sebesar 0.000 . Karena nilai signifikansi $<0,05$ (dibawah 0,05) maka hipotesis Ho ditolak dan $\mathrm{Ha}$ diterima. Hasil ini membuktikan bahwa variabel Earnings Per Share (EPS) memiliki pengaruh yang signifikan terhadap Harga Saham.

Variabel Net Profit Margin (NPM) didapat nilai $t$ sebesar 2.594 dengan tingkat signifikansi sebesar 0.12. Karena nilai signifikansi $<0,05$ (dibawah 0,05) maka hipotesis Ho ditolak dan $\mathrm{Ha}$ diterima. Hasil ini membuktikan bahwa variabel Net Profit Margin (NPM) memiliki pengaruh yang signifikansi terhadap Harga Saham.

Variabel Debt to Equity Ratio (DER) didapat nilai $\mathrm{t}$ sebesar 0.987 dengan tingkat signifikansi sebesar 0.328 . Karena nilai signifikansi $>0,05$ (diatas 0,05) maka hipotesis Ho diterima dan $\mathrm{Ha}$ ditolak. Hasil ini membuktikan bahwa variabel Debt to Equity Ratio (DER) tidak berpengaruh signifikan terhadap Harga Saham.

\section{Model Regresi Berganda}

Analisis regresi berganda bertujuan untuk mengetahui ada atau tidaknya pengaruh variabel Earnings Per Share, Net Profit Margin, Debt to Equity Ratio sebagai variabel Independen terhadap Harga Saham sebagai variabel dependen.
Tabel Uji Regresi Berganda

\begin{tabular}{l|r|r}
\hline \multirow{2}{*}{ Model } & \multicolumn{2}{|c}{$\begin{array}{c}\text { Unstandardized } \\
\text { Coefficients }\end{array}$} \\
\cline { 2 - 3 } & \multicolumn{1}{|c}{ B } & \multicolumn{1}{c}{ Std. Error } \\
\hline (Constant) & -334.747 & 239.610 \\
EPS & 10.215 & 1.076 \\
NPM & 68.527 & 26.415 \\
DER & 178.680 & 180.953 \\
\hline
\end{tabular}

Dari tabel uji regresi berganda diatas, maka diperoleh persamaan regresi berganda sebagai berikut:

$\mathrm{Y}=-334.747+10.215 \mathrm{EPS}+$ 68.527NPM + 178.680DER

Keterangan :

$\mathrm{Y}=$ Harga Saham

$\mathrm{X}_{1}=$ Earnings Per Share

$\mathrm{X}_{2}=$ Net Profit Margin

$\mathrm{X}_{3}=$ Debt to Equity Ratio

Dari persamaan diatas diketahui bahwa konstanta sebesar -334.747 menyatakan bahwa jika Earnings Per Share, Net Profit Margin, dan Debt to Equity Ratio bernilai konstan, maka harga saham menurun sebesar Rp. 334,747/lembar.

Earnings Per Share mempunyai nilai koefisien regresi sebesar 10,215 menyatakan bahwa setiap kenaikan Earnings Per Share sebesar 1\% akan diikuti dengan kenaikan harga saham sebesar 10,117/lembar.

Net Profit Margin mempunyai nilai koefisien regresi sebesar 68,527 menyatakan bahwa setiap kenaikan Net Profit Margin sebesar 1\% maka akan diikuti dengan kenaikan harga saham sebesar 68,527/lembar.

Debt to Equity Ratio mempunyai nilai koefisien regresi sebesar 178,680 menyatakan bahwa setiap kenaikan Debt to Equity Ratio sebesar 1\% akan 
diikuti dengan kenaikan harga saham sebesar 178,680/lembar.

\section{Pembahasan}

Earnings Per Share atau laba per saham adalah menunjukan pemberian keuntungan perusahaan kepada para pemegang saham dari setiap lembar saham yang dimiliki. Laba biasanya menjadi dasar penentuan dividen dan kenaikan nilai saham di masa datang. Oleh karena itu, para pemegang saham biasanya tertarik dengan angka EPS yang dilaporkan perusahaan (Prastowo,2011:99). Bagi para investor, informasi EPS merupakan informasi yang paling mendasar dan berguna, karena bisa menggambarkan prospek Earnings perusahaan di masa depan. EPS biasanya menjadi perhatian bagi para pemegang saham. Semakin tinggi EPS suatu perusahaan berarti semakin besar Earnings yang akanditerima investor dari investasinya tersebut, sehingga bagi perusahaan peningkatan EPS tersebut dapat memberi dampak positif terhadap harga sahamnya di pasar.Hasil uji hipotesis secara parsial menunjukan bahwa variabel EPS memiliki nilai signifikansi sebesar 0,000 atau lebih kecil dari 0,05. Ini menunjukan bahwa secara parsial variabel EPS berpengaruh signifikan terhadap harga saham perusahaan. Hasil penelitian ini mendukung penelitian yang dilakukan oleh Obeidat (2009), Wijayanti (2010), Nurfadillah (2011), Ahmad Husaini (2012), dan Atika Jauhari (2012), Qoribulloh (2013) yang menyatakan bahwa variabel Eanings Per Share memiliki pengaruh signifikan terhadap harga saham. Hasil ini juga membantah penelitian yang dilakukan oleh Sugiarti (2007), Zen (2009), dan
Meythi (2010) yang menyatakan bahwa variabel Earnings Per Share tidak memiliki pengaruh yang signifikan terhadap harga saham.

Net Profit Margin adalah suatu rasio yang digunakan untuk mengetahui seberapa besar laba bersih yang dihasilkan oleh suatu perusahaan dalam setiap penjualan yang dilakukan.Rasio ini memberi gambaran mengenai kemampuan perusahaan dalam menekan biaya-biaya operasionalnya sehingga menghasilkan laba bersih dalam suatu periode tertentu. Rasio NPM menjadi salah satu perhatian para investor karena semakin tinggi rasio ini semakin baik karena kemampuan perusahaan dalam mendapatkan laba bersih melalui penjualannya cukup tinggi sehingga membuat laba per saham perusahaan pun akan meningkat yang berarti akan menghasilkan keuntungan bagi investor. Begitu pun sebaliknya, jika rasio ini semakin rendah maka kemampuan perusahaan dalam mendapatkan laba dari setiap penjualannya dianggap rendah.Ini menggambarkan bahwa perusahaan tidak mampu menekan biaya biaya operasional yang membuat laba bersih yang dihasilkan perusahaan dari setiap penjualannya menurun.Hasil uji hipotesis secara parsial menunjukan bahwa variabel NPM memiliki nilai signifikansi sebesar 0,012 atau lebih kecil dari 0,05. Ini menunjukan bahwa secara parsial variabel NPM berpengaruh signifikan terhadap harga saham. Hasil penelitian ini mendukung penelitian yang dilakukan oleh Anisma, Hutami dan Jauhari (2012) dan Qoribulloh (2013) yang menyatakan bahwa NPM berpengaruh signifikan terhadap harga saham. Hasil ini juga 
membantah penelitian yang dilakukan oleh Husaini (2012) yang menyatakan bahwa NPM tidak memiliki pengaruh yang signifikan terhadap harga saham.

Debt to Equity Ratio (DER) termasuk dalam rasio solvabilitas.Rasio solvabilitas menggambarkan kemampuan perusahaan dalam memenuhi kewajiban jangka panjangnya.DER adalah perbandingan antara utang dan ekuitas.Rasio ini menunjukan risiko perusahaan, dimana semakin rendah DER mencerminkan semakin besar kemampuan perusahaan dalam menjamin utangnya dengan ekuitas yang dimiliki. Semakin tinggi proporsi DER menyebabkan laba perusahaan semakin tidak menentu dan menambah kemungkinan tidak dapat memenuhi kewajiban pembayaran utangnya (Nurfadillah:2011). Hasil uji hipotesis secara parsial menunjukan bahwa variabel DER memiliki nilai signifikansi sebesar 0,328 atau lebih besar dari 0,05 . Ini menunjukan bahwa secara parsial variabel DER tidak berpengaruh signifikan terhadap harga saham.Hal ini menunjukan bahwa investor tidak memandang DER sebagai salah satu komponen penting dalam melakukan investasi dan tidak berpengaruh terhadap pergerakan harga saham suatu perusahaan.Hasil ini mendukung penelitian sebelumnya yang dilakukan oleh Subiyantoro, Anastasia (2003), dan Nurfadillah (2011) yang menyatakan bahwa DER tidak memiliki pengaruh yang signifikan terhadap harga saham.Hasil ini juga membantah hasil penelitian yang dilakukan oleh Stella (2009), Jauhari (2012) dan Qoribulloh (2013) yang menyatakan bahwa DER berpengaruh terhadap harga saham.
Berdasarkan pengujian secara simultan menunjukan bahwa nilai $\mathrm{F}$ sebesar 47.651 dengan nilai signifikansi 0,000 atau lebih kecil dari 0,05 ini menunjukan bahwa secara simultan seluruh variabel independen dalam penelitian ini (EPS,NPM,DER) berpengaruh signifikan terhadap harga saham.

Berdasarkan pengujian koefisien determinasi nilai Adjusted $\mathrm{R}$ square adalah sebesar 0,703. Artinya pengaruh variabel independen yang terdiri dari Earnings Per Share, Net Profit Margin, Debt to Equity Ratio terhadap harga saham sebesar 0,703 atau $70,3 \%$. Hal ini berarti bahwa secara bersama sama variabel independen dapat mempengaruhi harga saham sebesar 70,3\%.

\section{SIMPULAN}

Setelah melakukan analisis dan pengujian hipotesis pengaruh Earnings Per Share, Net Profit Margin, Debt to Equity Ratio terhadap Harga Saham pada perusahaan manufaktur sektor industri barang konsumsi yang terdaftar di BEI periode 2009-2012, maka dapat ditarik kesimpulan sebagai berikut:

1. Hasil uji hipotesis secara parsial menunjukan bahwa variabel Earnings Per Share berpengaruh signifikan terhadap harga saham perusahaan manufaktur sektor industri barang konsumsi yang terdaftar di BEI.

2. Hasil uji hipotesis secara parsial menunjukan bahwa variabel $\mathrm{Net}$ Profit Margin berpengaruh signifikan terhadap harga saham perusahaan manufaktur sektor industri barang konsumsi yang terdaftar di BEI. 
3. Hasil uji hipotesis secara parsial menunjukan bahwa variabel Debt to Equity Ratio tidak berpengaruh signifikan terhadap harga saham perusahaan manufaktur sektor industri barang konsumsi yang terdafatar di BEI

\section{DAFTAR PUSTAKA}

Anastasia, Njo (2003). Analisis Faktor Fundamental Dan Risiko Sistematik Terhadap Harga Saham Properti Di BEJ. Jurnal Akuntansi \& Keuangan Vol. 5 No. 2, Nopember 2003:123-132

Anisma, Yuneista (2012). FaktorFaktor Yang Mempengaruhi Harga Saham Perusahaan Perbankan Yang Listing Di Bursa Efek Indonesia (BEI). Jurnal Sosial Ekonomi Pembangunan Tahun 11 No.5, Maret 2012

Anoraga, Pandji \& Pakarti, Piji ( 2006).

Pengantar Pasar Modal. Jakarta:

PT RINEKA CIPTA.

Darmadji, Tjiptono., \& Fakhruddin, Hendy M. (2012). Pasar Modal Di Indonesia Edisi 3. Jakarta: Salemba Empat.

Fahmi, Irham (2011). Analisis Laporan Keuangan. Jakarta: Alfabeta

Ghozali, Imam (2006). Aplikasi Analisis Multivariate dengan Program SPSS. Semarang: Badan Penerbit Undip.

Halim, Abdul (2005). Analisis Investasi. Jakarta: Salemba Empat.

Hanafi dan Halim (2012). Analisis Laporan Keuangan. Yogyakarta: Sekolah Tinggi Ilmu Manajemen YKPPN
Harahap, Sofyan Syahri (2010). Analisis Kritis Atas Laporan Keuangan. Jakarta: RajaGrafindo.

Husaini, Ahmad (2012). Pengaruh Variabel Return On Assets, Return On Equity, Net Profit Margin Dan Earnings Per Share Terhadap Harga Saham Perusahaan. Jurnal Profit, Volume 6, Nomor 1, Juni 2012

Hutami, Putri Rescyana (2012). Pengaruh Dividen Per Share, Return On Equity Dan Net Profit Margin Terhadap Harga Saham Perusahaan Industri Manufaktur Yang Tercatat Di Bursa Efek Indonesia Periode 2006-2010

Husnan, Suad (2009). Teori Portofolio \& Analisis Sekuritas Edisi Keempat. Yogyakarta: Sekolah Tinggi Ilmu Manajemen YKPN.

Jauhari, Atika (2012). The Company Fundamental Factors And Systematic Risk In Increasing Stock Price. Journal of Economics,Business, And Accountancy Ventura Volume 15, No 2 August 2012, Pages 245256

Kashmir (2011). Analisis Laporan Keuangan. Jakarta: RajaGrafindo

Kieso dan Weygandt (2007). Akuntansi Intermediate Edisi Keduabelas Jilid 1. Jakarta: Erlangga

Menaje, Placido M. (2012). Impact Of Selected Financial Variables On Share Price Of Publicy Listed Firm In The Philippines. American International Journal Of Contemporary Research Vol 2. No. 9 September 2012.

Meythi (2011). Pengaruh Likuiditas Dan Profitabilitas Terhadap Harga Saham Perusahaan 
Manufaktur Yang Terdaftar Di Bursa Efek Indonesia. Jurnal Bisnis Manajemen dan Ekonomi, Volume 10, No.2 Mei 2011, hal 2671-2684

Nurfadillah, Mursidah (2011). Analisis Pengaruh Earnings Per Share, Debt To Equity Ratio Dan Return On Equity Terhadap Harga Saham PT Unilever Indonesia Tbk. Jurnal Manajemen Dan Akuntansi Volume 12 No 1 April 2011.

Obeidat, Mohammed Ibrahim (2009). The Internal Financial Determinants of Common Stock Market Price: Evidence From Abu Dhabi Securities Market. Journal of Economic \& Administrative Sciences Vol. 25, No. 1, June 2009.

Prastowo, Dwi (2011). Analisis Laporan Keuangan Konsep dan Aplikasi. Yogyakarta :Sekolah Tinggi Ilmu Manajemen YKPN

Qoribulloh, Rizal (2013). Pengaruh Rasio Keuangan Terhadap Harga Saham Pada Perusahaan Manufaktur Yang Terdaftar Di Bursa Efek Indonesia Tahun 2011. Jurnal Pendidikan \& Ekonomi Vol 2 No 2 tahun 2013

Samsul, Mohamad (2006). Pasar Modal \& Manajemen Portofolio.Jakarta: Erlangga

Sanusi Anwar (2011). Metodologi Penelitian Bisnis. Jakarta: Salemba Empat.

Sitanggang (2012). Manajemen Keuangan Perusahaan Dilengakapi Soal dan Penyelesaiannya. Jakarta: Mitra Wacana Media
Stella (2011). Pengaruh Price Earnings Ratio, Debt To Equity, Return On Asset dan Price To Book Value Terhadap Harga Saham. Jurnal Bisnis dan Akuntansi Vol. 11 No 2 Agustus 2009 Hlm 97-106

Subiyantoro, Edi (2003). Analisis Faktor - Faktor Yang Mempengaruhi Harga Saham. Jurnal Manajemen \& Kewirausahaan Vol 5 No 2 September 2003:171-180

Sugiarti, Yenni (2007). Pengaruh Informasi Keuangan Terhadap Harga Saham Perusahaan Perbankan. Jurnal Akuntansi dan Teknologi Informasi, Vol 6 No 2 November 2007 hal 79-92

Tandelilin, Eduardus (2010) Portofolio dan Investasi Teori dan Aplikasi Edisi Pertama. Yogyakarta: Kanisius.

Widoatmodjo, Sawidji (2005). Cara Sehat Investasi di Pasar Modal Pengantar Menjadi Investor Profesional. Jakarta: PT. Elex Media Komputondo.

Wijayanti (2010). Analisis Kinerja Keuangan Dan Harga Saham Perbankan Di Bursa Efek Indonesia (BEI). Journal Of Indonesian Applied Economics Vol. 4, No. 1 Mei 2010, 71-80.

Zen, Fadia (2009). Earnings Per Share (EPS), Book Value (BV), Economic Value Added (EVA) dan Harga Saham. Jurnal Manajemen Gajayana Vol.6, No.2, November 2009, 151-162. 